\title{
Transsituationaaliset esineet ja asiat osallistavassa taiteessa
}

\section{Riikka Haapalainen}

Vuonna 1969 yhdysvaltalainen käsitetaiteilija Douglas Huebler kirjoitti taiteellisista lähtökohdistaan tähän tapaan: 'Maailma on täynnä esineitä, enemmän tai vähemmän kiinnostavia; en halua lisätä niitä enempää.» Hueblerin ratkaisu esineiden kylläännyttämässä maailmassa oli dematerialisoida taiteellinen työskentely ja dokumentoida inmislajia ja -eloa sanojen, karttojen, piirrosten sekä valokuvien kautta. Reilu viisikymmentä vuotta Hueblerin kannanoton jälkeen sen sisältöä on helppo lukea kulutus- ja ilmastokriittisesti. Kun maat ja meret täyttyvät tavarapaljoudesta, voi olla eettisesti vaikea perustella luonnonvaroja kuluttavia uusien - kiinnostavien tai vähemmän kiinnostavien - (taide-)esineiden välttämättömyyttä. IImastokriisin aikana taiteen kysymykset eivät ole vain taiteen kysymyksiä.
Aineeton ja esineetön taide ${ }^{2}$ voisi olla yksi keino lähestyä esineiden kumulatiivisen kasvun kysymyksiä. Esimerkiksi osallistavaa taidetta eli taidetta, jonka ennakkoehtona on yleisön osallistuminen teoksen tuotantoprosesseihin, onkin usein korostuneesti tarkasteltu aineettomana sosiaalisten sidosten taiteena. ${ }^{3}$ Tämä osallistavien taideteosten oletettu aineettomuus on kuitenkin tutkimuksellinen haaste. Osallistavia prosesseja ei koskaan voi nähdä tai tuntea kokonaan. Ne ovat annetusti epämääräisiä ja monitulkintaisia: hetkellisiä, hajanaisia, jälkikäteisiä ja yhteismitattomia. Niissä katsoja-osallistujan ja katsomisen kohteen eli taideteoksen väliselle etäisyydelle perustuva representatiivinen suhde on korvautunut monenlaisten ja satunnaisten ainesten läsnäololla. Miten käsitellä tätä sekavaa ja pakenevaa moninaisuutta?

\section{Taiteen esineistä ja asioista}

Lähtökohtanani tälle tekstille on ajatusleikki siitä, mitä tapahtuisi jos osallistavaa taidetta tarkastelisikin inmisosallistujien rinnalla myös esineiden näkökulmasta. Pohdin esineiden ja muiden ainesten toimijuuksia taiteessa kahdesta eri suunnasta. Yhtäältä otan tarkasteluuni tanskalaisen taiteilijaryhmä Superflexin Free Shop -intervention, jonka tapahtumapaikkana on kuluttamisen esineiden ja inmisten kanssaolemisen - tyypillisin näyttämö, kauppa. ${ }^{4}$ Ja toisaalta tarkastelen Tatu Gustafssonin soap wi-fi stilts -näyttelyä (Titanik, Turku, 2019), joka osaltaan jatkoi Hueblerin ajatusta taiteesta, joka ei lisäisi uusia esineitä maailmaan.

Siirryn ensin Free Shopiin Itäkeskuksen Ruohonjuuri-kauppaan ja vuoteen 2011 (Kuvat 1-3). Tilanne vaikuttaa jokapäiväiseltä ja arkiselta kaupassa käynniltä. Mutta silti kaikki ei ihan ole kuten tavallisesti. Teoksen

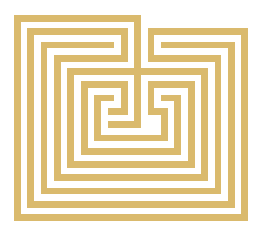




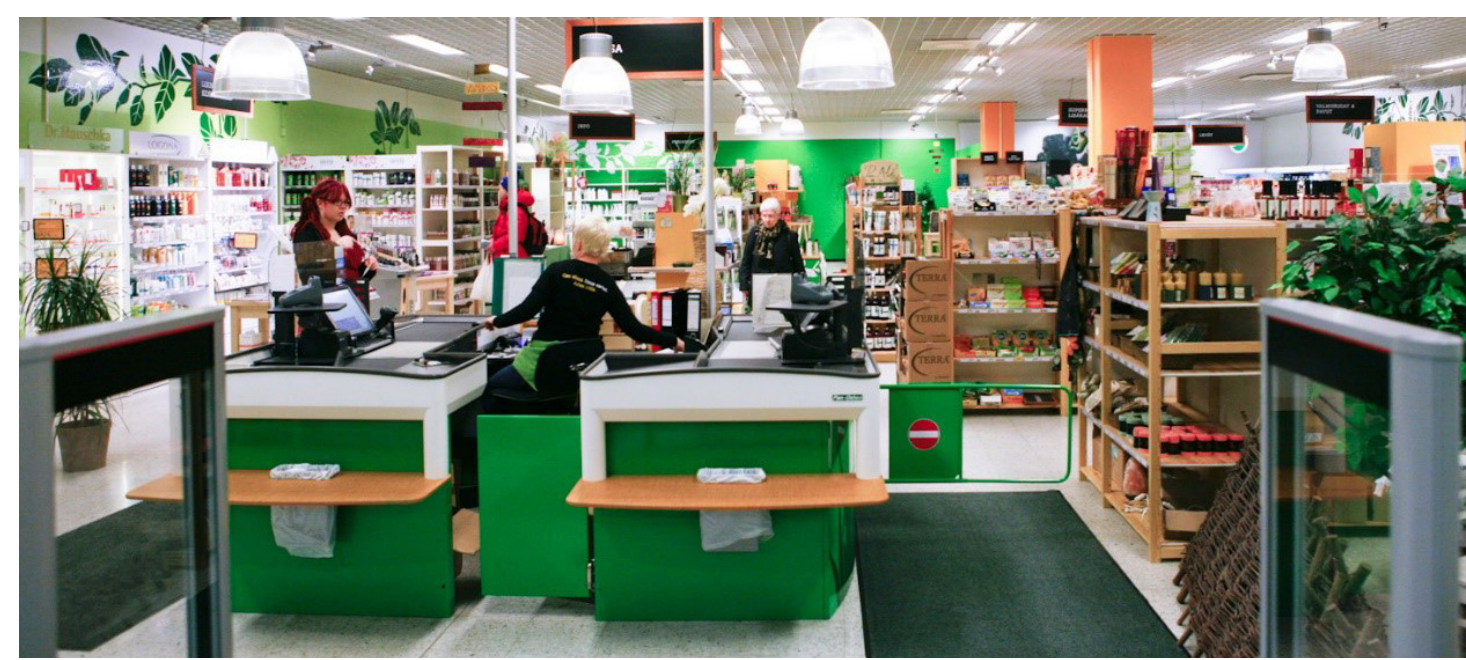

Kuva 1. Superflex, Free Shop (Ruohonjuuri, Itäkeskus, Helsinki), 2011. Kuva: IHME-nykytaidefestivaali/Neikko Somerpuro.

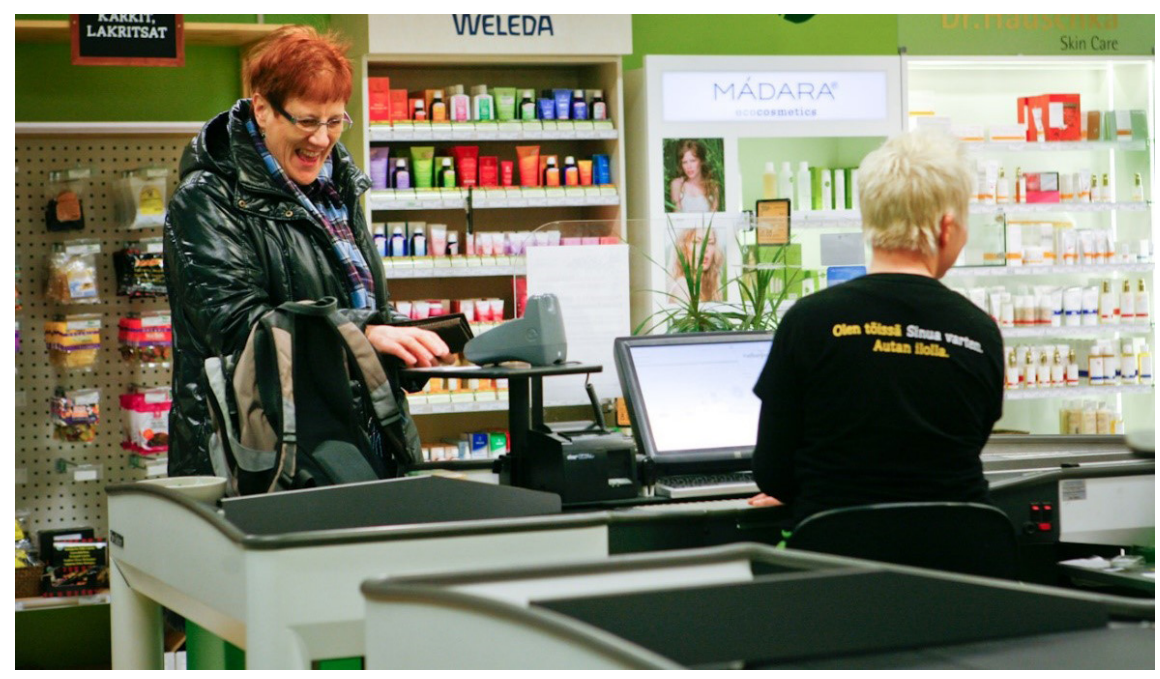

Kuva 2. Superflex, Free Shop (Ruohonjuuri, Itäkeskus, Helsinki), 2011. Kuva: IHME-nykytaidefestivaali/Veikko Somerpuro.

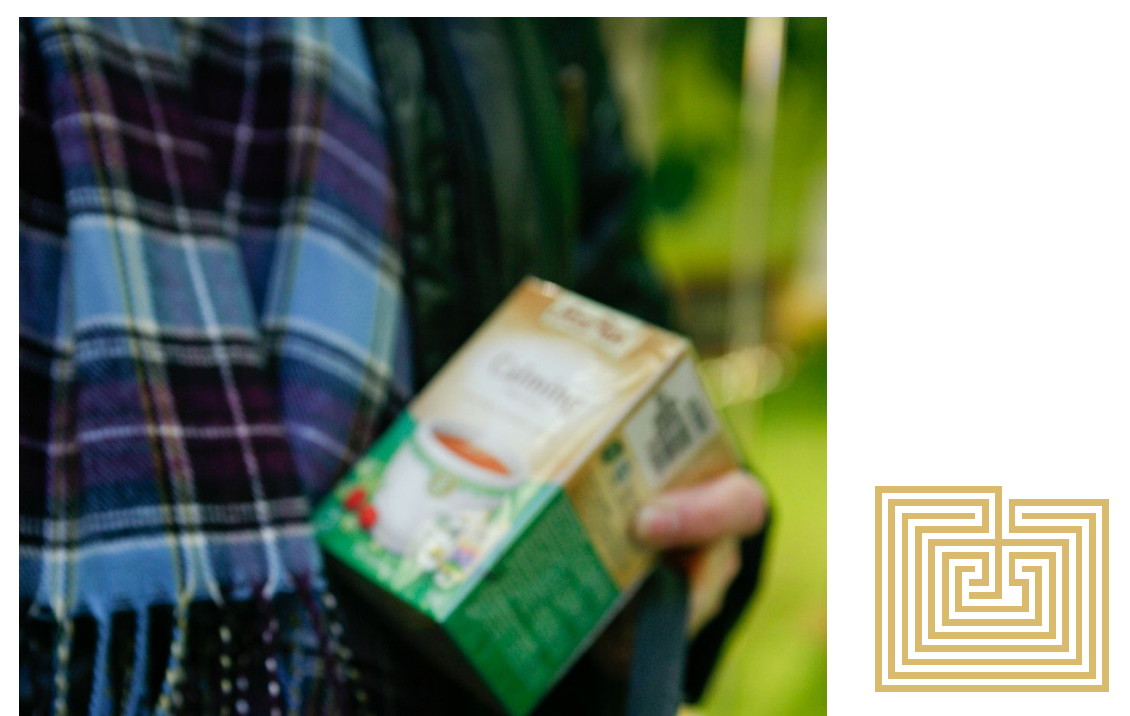




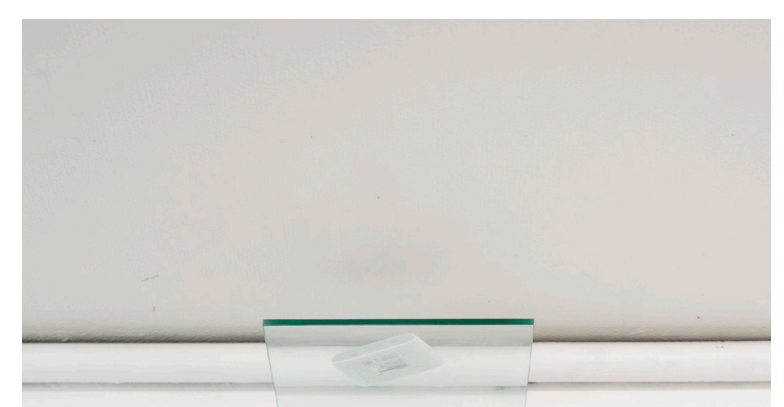

Kuva 4. Tatu Gustafsson, Wi-fi from someone to everyone, 2019. Soap wi-fi stilts -näyttely, Titanik-galleria. Kuva: Susanna Selin.

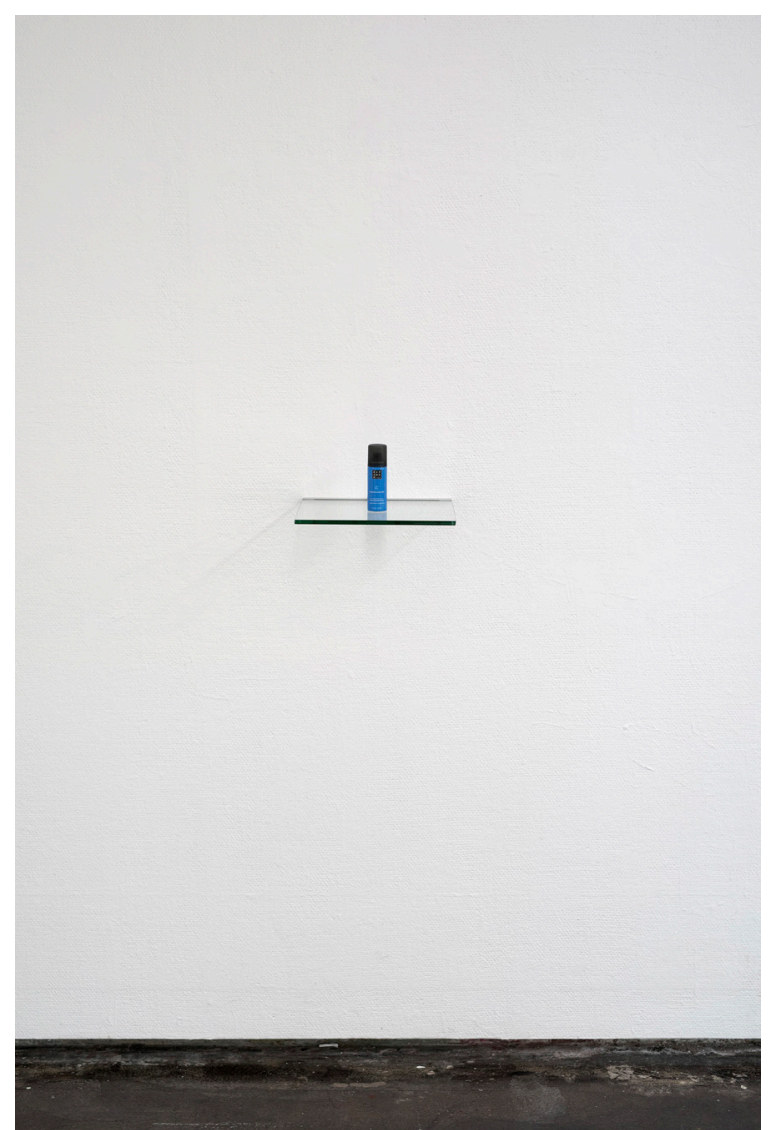

Kuva 5. Tatu Gustafsson, Deodorant from someone who researches the future, 2019. soap wi-fi stilts -näyttely, Titanik-galleria. Kuva: Susanna Selin.

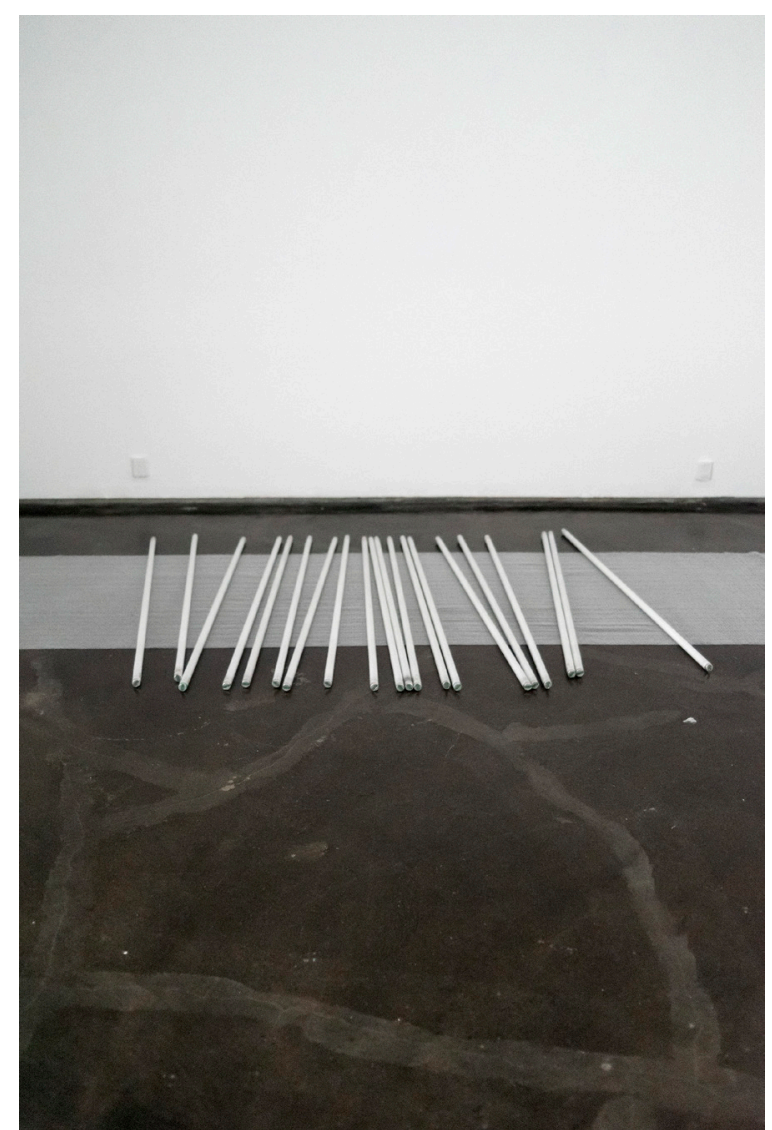

Kuva 6. Tatu Gustafsson, Fluorescent tubes from the gallery, 2019. soap wi-fi stilts -näyttely, Titanik-galleria. Kuva: Susanna Selin.

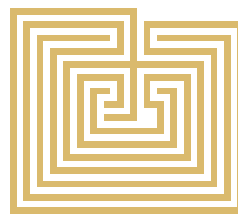


mottona on: "Kaikki, mitä asiakas haluaa ostaa, on ilmaista. Free Shop voi tapahtua missä tahansa, milloin tahansa, kenelle tahansa." Tietyn ajan kaikki se, mitä asiakas tuo kaupan kassahihnalle maksettavaksi onkin ilmaista. Kuvassa 2 teostapahtumaan tietämättään joutunut osallistuja ei vielä ole täysin oivaltanut, ettei ostoksia vastaan tällä kertaa vaaditakaan rahaa. Siksi huomio kuvassa kiinnittyy erityisesti teoksen piilokameramaiseen asetelmallisuuteen, kassan ja asiakkaan ennakoivaan jännitteeseen ja sen yllätykselliseen purkuun. Onko ostosten ilmaisluonteen paljastuminen myös se momentti, jossa teoksen 'taide' tapahtui? Vai piileekö se kassan ja asiakkaan välisessä vuorovaikutuksessa? Mikä interventiossa paikantuu varsinaiseksi taiteeksi ja mikä on sen suhde erilaisiin jälkiin, tallenteisiin, kokemuksiin ja teksteihin, joita prosessista samanaikaisesti ja viiveellä väistämättä syntyy?

Free Shopin kaltaiselle osallistavalle teokselle voi pyrkiä luomaan muotoa tai rakennetta ainakin kolmella ajallisella tarkastelu- ja toimintatavalla. Ensinnäkin voi tuoda näkyville interventiota valmistelevan työn taustoittamalla Superflexin taiteellista ajatte- lua; sitä, kuinka Superflex halusi tutkia mahdollisuuksia vastatalouteen ja rahan vallan kyseenalaistamiseen. ${ }^{5}$ Lisäksi voi taustoittaa teoksen tuotantoprosessiin liittyneitä käytännöllisempiä ennakkovalmisteluja, joita Free Shopin tapauksessa olivat esimerkiksi neuvottelut interventioon osallistuneiden myymälöiden kanssa. Toiseksi tarkastelussa voi kiinnittyä teoksen varsinaiseen tapahtumiseen ja siinä tiivistyvään, arjen rutiinit katkaisevaan sosiaaliseen yhdessäoloon. Free Shopissa tämä merkitsisi kaikkea sitä, mitä kaupassa inmisten välillä tapahtui intervention kestäessä. Kolmas ajallinen taso on intervention jälkeiseen re-presentaatioon, uudelleen esittämiseen ja tulkintaan liittyvät sisällöt ja käytännöt, kuten esimerkiksi teoksen näytteilleasettamisen ratkaisut ja osallistujien kertomukset. Free Shopin jälkituotantoon sisältyy myös teoksen dokumentaatio, joka toteutettiin tarkasti Superflexin ennalta määrittelemien ehtojen mukaisesti.

Osallistavat taideteokset ovat aina samaan ja eri aikaan moniaalla, muualla ja tässä joko prosesseina tai tilanteeseen liittyvinä tallenteina; erilaisina narratiiveina, muistoina ja laajenevina verkostoina. Siksi väitän, että teokset ovat annetusti transsituationaalisia, yksittäisen vastaanottotilanteen ylittävää moninaisuutta. ${ }^{6}$ Transsituationaalisina teosten vastaanotto ei koskaan voi olla kattava, kokonainen tai lopullinen: niiltä puuttuu keskiö. Aina joku, jokin tai jotain jää teoksesta tavoittamatta. Siksi myös teoksen tapahtumis- ja tarkastelukenttää sekä sen dualistisia lähtökohtia on hajautettava. Taiteen tarkastelu transsituationaalisena kutsuu avartavaa, moninaistavaa ja -arvoistavaa luentatapaa suhteessa teoksen aineellisuuteen, ajallisuuteen ja sosiaalisuuteen: moninlukemista ohi yleisen ja inmiskeskeisen ymmärryksen taideteoksen luonteesta. ${ }^{7}$

Taidehistorian tutkimus oli pitkään objektikeskeistä: sen tutkimuskohteita, esineitä, ei tarvinnut kyseenalaistaa. Taidehistorian esine oli singulaari; kestävä, kiinteä ja erityisyydellään kaikesta muusta rajautuva. Samalla taidehistorian esineistö tuotti induktiivista havaintoa maailmasta: taiteen kautta voidaan löytää esteettisen ja historiallisen tarkastelun rinnalla laajempi ymmärrys yhteiskunnasta ja kulttuurista. Tämän erityisen ja tunnistettavan objektin lähtökohta kuitenkin ylläpitää ja luo yleisyyttä ja yksiaikaisuutta; hegemonisia ja hierarkkisia rakenteita taiteen kentälle. 
Myös taide-esineiden ja ihmisten välinen suhde on ollut selkeän asetelmallinen ja kyseenalaistamaton: inmiset (katsojat) ovat suhteessa taide-esineisiin vastakkaisissa tai projisoivissa positioissa: tekemässä tulkintoja, synnyttämässä merkityksiä, nimeämässä ja luokittelemassa. Tätähän taidehistorialliseen tutkimukseen - tarkkaan katsomiseen - liittyvä taideteoksen kontemplaatio paradigmaattisesti on. ${ }^{8}$ Taidehistorian objektit on ensin katseen kohdistamisella eriytetty muusta ympäristöstä, minkä jälkeen niille on kielen, tulkintojen ja teorioiden, kautta luotu uudelleen yhteys takaisin maailmaan tai vähintäänkin vallitseviin taiteen diskursseihin.

Taidehistorioitsija Claire Bishop on esitellyt myös osallistavan taiteen keskeisenä toimijuuskategoriana katsojuuden (spectatorship). ${ }^{9}$ Siten Bishop jatkaa sekä singulaarin yleisön ajatusta että moderniteetille tunnusomaista ajatusta katseen kautta hahmottuvasta ja haltuun otettavasta maailmasta. Katsojuus pitää sisällään samanaikaisen ajatuksen sekä osallisuudesta että vääjäämättömästi ulkopuolisesta tarkkailijapositiosta. Tämä positio alleviivaa taiteilijan ja maallikon välistä erottelua: maallikoilla - katsojilla - ei ole katsoessaan pääsyä taiteilijan tavoin teoksen 'sisään', vaan he aina jäävät etäisemmiksi tarkkailijoiksi, vastakkaiseen suhteeseen sekä teokseen että taiteilijaan.

\section{Osallistavan taiteen oletettu immateriaalisuus}

Taiteen niin sanottua osallistavaa käännettä on 1990-luvulta alkaen luonnehdittu paradigmaattisena siirtymänä esineistä inmisiin, materiaalisesta immateriaaliseen. ${ }^{10}$ Kun taideteos syntyy ja toteutuu osallistumisen prosesseissa - sosiaalisessa vaihdossa ja vuorovaikutuksessa - on houkuttelevaa jättää sen arkisen aineellinen puoli vähemmälle huomiolle. Esineet ja asiat ovat osallistavien prosessien sokea piste tai tiedostamaton, ne ovat epäkiinnostavia ja ei-erityisiä. Tämä onkin ymmärrettävää, sillä esimerkiksi Free Shopin kaltaisen teoksen esinemaailma on kovin satunnainen. Teoksen eri toteutusversioiden valokuvatallenteissa näkyy muun muassa apteekkituotteita, päivittäistavaroita, äänilevyjä, juustoja ja sesonkikasviksia. Esineet ja asiat ovat jo kaupan hyllyillä ja vitriineissä niin kuin aina muulloinkin, ilman taiteilijan valintaa tai kontrollia. Ne lavastavat ja kehystävät teostapahtumaa, kuljettavat inmisiä toistensa luokse, liittävät heidät yhteen ja ainakin hetkellisesti myös pitävät heitä yhdessä.

Ja juuri tämän jo-siellä-olemisen takia osallistavan taiteen esineet eivät tutkimuksellisesti ole olleet kiinnostavia. ${ }^{11}$ Free Shopin kulutushyödykkeet ovat jääneet anonyymeinä, tunnistamattomina ja toisinnettavina teosluennan marginaaleihin. Tämä osoittaa taidekirjoittamisen inmiskeskeisyyden, jota muun muassa posthumanistinen ja uusmaterialistinen tutkimus on kritisoinut.

Osallistaviin prosesseihin päätyvien esineiden materiaalinen toimijuus eroaa sattumanvaraisuudessaan esimerkiksi readymadejen ehdottamasta esineisyydestä. Readymaden ajatus edellyttää taiteilija-tekijän kontrollia: kohottaessaan readymaden taiteeksi taiteilija valitsee sille samalla myös tilan ja paikan. Free shopin kaltaisessa esinekoosteessa taiteilija on jo ennalta luopunut kontrollistaan. Esineet jo-siellä sallivat sekä sattumanvaraisuuden että yllättävät ja ei-toivotut yhteydet. Modernin eriyttävä ja rajaava paradigma murtuu kaiken sallimisella ja hierarkioiden kumoutumisella.

Suhteessa moderniin taiteeseen osallistavalla taiteella ajatellaan olevan kaksi peruslähtökohtaa: yhtäältä osallistava tai- 
de purkaa taiteen tekemisen ja vastaanoton kaksinapaisuutta ääripäinään aktiivinen taiteilija ja passiiviseksi oletettu vastaanottaja-katsoja, ja toisaalta se korostaa taiteen poliittista ja sosiaalista kontekstia yli sen materiaalisen olomuodon. Kaikkialle levittäytyvä ja monenlaisen muodon saava taide siirtää katsojan teoksen vastaanottajasta tai osallistujasta tilanteeseen, jossa teos on ja tapahtuu. Se aktivoi katsojan suhteen maailmaan. Osallistava taide - kuten arkinen elämäkin - osallistaa kokonaisvaltaiseen, moniaistiseen tilanteeseen.

Taiteen osallistavasta käänteestä on kirjoittanut muun muassa Suzana Milevska, jonka mukaan käänteeseen vaikutti 1990-luvun filosofinen ja sosiologinen keskustelu, erityisesti poststrukturalismin esille tuomat ajatukset tekijän kuolemasta ja relationaalisen sosiologian ymmärrys yhteiskunnan yhteiskunnallistumisesta dynaamisesti erilaisissa vuorovaikutussuhteissa. ${ }^{12}$ Tässä dynamiikassa moni asia määrittyy toisin. Esimerkiksi Irit Rogoffille taiteeseen osallistuminen näyttäytyy aktiivisena ja hierarkiattomana toimijuutena (agency) ja osallisuutena tai osakkuutena (stakeholder). ${ }^{13}$ Osakkuuden käsite osoittaa sidoksen, joka kaikilla on suhtees- sa muihin ihmisiin ja asioihin: taideteokseen osallistuessaan jokainen osaltaan tuottaa ja muokkaa uudelleen teoksen merkityksiä ja sisältöjä - myös tahattomasti ja passiivisena. Siten toimijuus ja osakkuus ovat käsitteinä transsituationaalisia: ne ylittävät sen, mihin kulloinkin aina osallistutaan. Ne avaavat suhteita yli varsinaisen taideteoksen ja ovat siten myös ajallisesti ja toiminnallisesti avoimempia ja enemmän kytköksissä muuhun. Samalla kun taideprosessi liittää yksilöt yhteen, aktivoituu myös heidän suhteensa elämään, yhteisöön ja olemiseen.

Maria Lind on luonnehtinut osallistumista siirtymänä taiteilija-katsoja-erottelusta taiteilijan ja muiden väliseksi yhteistoiminnaksi: mahdollisuutena osallistua johonkin, jonka joku toinen on luonut tai käynnistänyt mutta jonka sisältöihin voi itse silti vaikuttaa. ${ }^{14}$ Osallistavissa prosesseissa se, mitä taiteilija luo, ei ole enää taideteos tai taide-esine perinteisessä mielessä, sillä siltä puuttuu lopullinen muoto ja keskiö, hierarkkisesti jäsentynyt ja tarkastelua ohjaava suunta. Teos on pikemminkin väline tai tilanne, jossa taiteilija on yhdessä yleisönsä kanssa jakamassa ja saamassa. Myös Nicolas Bourriaud on relationaalisen estetiikan ajattelussaan samoilla linjoilla. Hänkin korostaa taiteen sosiaalisten suhteiden, relaatioiden merkittävyyttä. Hänelle taiteilija ei ole tekijä vaan pikemminkin mahdollistaja tai alullepanija. Siksi taiteessa ei korostuisi materiaalinen työ vaan teoksen synnyttämiin sosiaalisiin suhteisiin perustuvat esteettiset muodot. ${ }^{15}$ Huomio keskittyy inmisten väliseen yhdessäoloon, sosiaalisiin yhteenliittymiin aineellisten sijaan. Samalla relationaalisen estetiikan vaalima ajatus yhdessäolosta menettää kriittisen potentiaalinsa ja pelkistyy tai pikemminkin yleistyy arvovapaaksi, porvarilliseksi urbaaniksi viihtymiseksi - vaikka juuri tämä kriittinen potentiaali on ollut Bourriaud'n relationaalisen estetiikan ytimessä. Hänelle taiteen tärkeä lähtökohta on sen kyky häiritä arkea tuomalla kaupallistuneisiin, spektaakkelin läpäisemiin ihmistenvälisiin suhteisiin uusia "sosiaalisia säröjä", epätavanomaisuutta. ${ }^{16}$ Säröissä korostuvat vaihtoehtoiset tavat kommunikoida ja synnyttää vaihtoa inmisten välille. Silti Bourriaud'n ajatus sosiaalisista halkeamista tarkoittaa lähinnä korjaavaa toimintaa, ei uudistavaa tai täysin uutta tuottavaa.

Claire Bishopin positio osallistavan taiteen keskusteluissa on ollut taide-erityisyydestä kiinnipitävää. Hän on kritisoinut voimakkaas- 
ti relationaalisen estetiikan esiin nostamia taiteen sosiaalisia ja eettisiä päämääriä. ${ }^{17}$ Hänen mukaansa taiteen sosiaaliset sisällöt ovat ylikorostuneet esteettisen kustannuksella. Osallistavassa taiteessa on keskitytty liikaa inmisten ja yhteisöjen sosiaaliseen muutokseen ja osallistamisen prosesseihin, jolloin taiteen erityisyys - teosten esteettinen laatu - on unohdettu. Bishopille keskeistä osallistavassa taiteessa onkin korostaa teosta 'taiteena' ja esteettisenä ilmiönä. Tämän vuoksi hän itse erottaa dualistisesti taiteen sosiaalisen ja esteettisen sisällön toisistaan. ${ }^{18}$

Bishop on tunnistanut osallistavan taiteen teoksista kaksi erilaista osallistumisen ulottuvuutta: yhtäältä osallistuminen voi tarkoittaa katsojan osallistumista yksin tai seurassa niin sanottuun interaktiiviseen taideteokseen ja installaatioon, ja toisaalta se voi olla kollektiivista osallistumista sosiaalisen elämyksen tuottamiseen. ${ }^{19}$ Ensimmäinen ulottuvuus tarkoittaisi katsojan fyysistä kiinnittymistä teokseen, joka on aineellisesti rajattavissa. Jälkimmäinen puolestaan viittaisi niihin taiteen osallistaviin aineettomiin ja yhteisöllisiin elämyksiin, joihin ei yhtä suoraan voi fyysisesti kiinnittyä.
Mutta ehkä sosiaalisuutta, esteettisyyttä ja aineellisuutta ei tulisikaan nähdä vastakkaisina arvoina. Ne ovat kaikki erilaisilla painotuksilla aina läsnä taiteessa ja sen vastaanottotilanteissa. Ja vielä enemmänkin, Bruno Latouria ${ }^{20}$ seuraten, on materiaalisen ja sosiaalisen erottelu mahdotonta, sillä inmisten keskinäiset suhteet ovat aina esineiden ja asioiden välittämiä. Osallistuminen voi olla vuorovaikutusta teoksen kanssa, osallistumista teoksen toteuttamiseen, mutta myös muuntuvia sosiaalisia tai seurallisia suhteita inmisten, asioiden ja ilmiöiden välillä. Siksi niitä voi tarkastella ainoastaan prosessuaalisesti ja relationaalisesti, suhteissa ja kytköksissä aina johonkin toiseen. Ja siksi osallistava taidekin on perustavanlaatuisesti materiaalista ja esinelähtöistä. ${ }^{21}$ Teosten materiaalisuus - teoksen mahdollistavat arkipäiväiset ja satunnaiset esineet ja asiat - on vain erilaisia transsituationaalisia suhteita. Näitä suhteita luonnehtii jatkuva keskinäisten voimasuhteiden koettelu, joka esimerkiksi Free Shopissa näyttäytyy ainakin ihmisten ja tavaroiden välisen konsumeristisen suhteen neuvotteluna.

Sosiologi Latourin esittämät ajatukset aineellisista yhteisöistä ja esineiden yhteisyyt- tä välittävistä toimijuuksista ovat yksinkertaisimmillaan inmiskeskeisiä, samalla tapaa kuin on sosiaalisesta estetiikasta kirjoittaneen Michel Maffesolin näkemys kuvista ja objekteista. Maffesolin mukaan objektien kautta voidaan sulautua yhteisölliseen maailmaan (samalla tavoin kuin esimerkiksi katolisessa kirkossa pyhimyskuvaa palvottaessa liitytään uskonnolliseen yhteisyyteen). ${ }^{22}$ Siten aineellinen todellisuus tulee määrittyneeksi ja muotoutuneeksi inmisen kautta - ei itsenäisesti, ennakoimattoman omalakisesti tai edes sekoittuen. Tätä inmiskeskeisyyttä jatkavat myös osallistavasta taiteesta kirjoitetut osallistumisen topologiat, jotka kartoittavat teoksen inmisosallistujien osallistumisen tapoja ja rajoja. ${ }^{23}$

Osallistavan taiteen erityisyys sosiaalisten suhteiden esille tuojana ei siten tarjoa radikaalisti uutta varhaisempaan taidekäsitykseen; se ainoastaan ylläpitää taiteen inmiskeskeisyyttä. Onhan taiteen vastaanotto ollut aina annetusti sosiaalista ja katsojaansa osallistavaa, eikä tähänkään taiteen osallistava käänne ole tuonut muutosta. Se on ainoastaan laajentanut ja moninaistanut taiteen käsitettä. Siksi osallistava taide ei itsessään tuo vaihtoehtoisia ja kestävämpiä 
toimintatapoja maailmaan, joka jo on kyllääntynyt tavaroista ja taide-esineistä.

\section{Ihmisten, esineiden ja asioiden kanssatoimijuus}

Taiteen osallistava käänne on merkinnyt vahvojen, singulaarien (taide-)esineiden puuttuessa käännöstä ihmisten ja yhteisöjen välisiin suhteisiin. Tässä käännöksessä esineet ja asiat hukkuivat inmistenvälisen osallistumisen sosiaalisen kohinan alle. Esineiden ja asioiden maailma oli liian jokapäiväistä, arkista ja vailla suoraa representatiivista suhdetta johonkin toiseen.

Kuten todettua, Latourille toimijuus on ihmisten lisäksi myös esineille kuuluva ominaisuus: esineet määrittelevät ja säätelevät inmisten välistä toimintaa. ${ }^{24}$ Muiden muassa filosofi Graham Harman on korostanut esineiden materiaalista voimaa Latouriakin radikaalimmin. Harmanin mukaan esineitä tulisi tarkastella itsenäisinä, inmisten vuorovaikutuksesta tai projektioista riippumattomina toimijoina. ${ }^{25}$ Myös uusmaterialisti Jane Bennett, jonka ajatukset materiaalisesta todellisuudesta ovat Harmanille vastakkaiset, on korostanut esineiden ja asioiden olevaisuutta riippumattomana inmisen toiminnoista tai interventioista. ${ }^{26}$ Mitä tällainen esineiden ja asioiden materiaalinen toimijuus, inmisestä riippumaton oleminen voisi tarkoittaa taiteessa? Esimerkiksi Free Shopissa keskeisenä teostapahtuman määrittäjänä on nollasummainen ostoskuitti (Kuva 3). Sen kädestä käteen siirtyminen merkitsee teokseen käsikirjoitettua toiminnallista huippukohtaa: hetkeä, jolloin tuotteiden ilmaisuus paljastuu ja asiakas saa tuta mahdottoman mahdolliseksi tulemisen, rahaan perustuvan markkinatalouden hetkellisen ja onnekkaan kumoutumisen. Kassakuitti paljastaa intervention taideluonteen.

Entä muuttuisiko Free Shopin esineistön toimijuus, jos ne siirrettäisiin pois kaupan hyllyiltä tunnuskuvallisemmalle taiteen areenalle, näyttelykontekstiin? Miten niiden toimijuuteen ja materiaalisuuteen vaikuttaisi paikka, jossa taiteen ja taide-esineen vastaanottotapaa ohjataan koodatummin kontemplatiiviseen ja käsitteellisempään tarkasteluun? Yhden alustan tälle pohdinnalle tarjoaa esimerkiksi Tatu Gustafssonin kesällä 2019 Turun Titanik-galleriaan kutsuma soap wi-fi stilts -näyttely. ${ }^{27}$ Näyttely esitti kysymyksen siitä, tarvitseeko taidenäyttelyyn tuottaa uusia tavaroita. Kysymys nousi tai- teen julkisiin esittämiskäytäntöihin liittyvästä uutuuden vaateesta, minkä voi nähdä ekologisesti kestämättömäksi.

Nimensä soap wi-fi stilts mukaisesti näyttelytilassa oli esillä muun muassa saippuapala, langattoman verkon mokkula ja puujalat. Silti näyttelyn esineet eivät olleet klassisia duchampilaisia teollisesti valmistettuja readymadeja, jotka taiteilijan tietoinen valinta oli kohottanut taideteoksiksi. Tässä muodonmuutoksessa teosesineen materiaalisuuden on nähty heikkenevän tai ohenevan laadultaan käsitteellisemmäksi, aineettomammaksi. Soap wi-fi stilts -näyttelyn materiaalinen esineistö oli arkisesta toiminta- ja käyttöympäristöstään irroitettua ja uudelleen sijoitettua lainatavaraa. Siksi esineiden taidestatus oli läpi näyttelyn häilyvä. Gustafsson oli pyytänyt esinelainoja itselleen kiinnostavilta inmisiltä tai instituutioilta, taikurista ja tulevaisuudentutkijasta museoon ja automarkettiin. Valikoimaan sisältyi myös Gustafssonin henkilökohtaisia tavaroita. Tällä tavoin Gustafsson pyrki kiertämään taiteilijuudelle asetetun odotusarvon uutuudesta ja uusien teosten valmistamisesta: luomaan näyttelyn, joka ei edellyttäisi mitään uutta. 
Gustafssonin näyttelyssä vierailleet esineet osoittivat myös sen, kuinka valmiiksi (ja ahtaaksi) kooditettua näyttelykonteksti on. Taidenäyttely rakenteena ja asioiden esittämisen muotona on niin vakiintunut ja pysyvä, että taiteen vastaanoton kaltainen suuntautuminen voidaan synnyttää käytännössä mille tahansa ilmiölle. Soap wi-fi stilts -näyttelyn esineistö ei kuitenkaan asettunut näyttelykoodeihin hangoittelematta vastaan. Ne koettelivat ainakin kolmella tasolla gallerianäyttelyä taiteen esille saattamisen muotona: ne synnyttivät kitkaa suhteessa luonnollistuneisiin ajatuksiin tekijyyydestä (omistajuudesta), rahasta ja ajallisuudesta. Ensinnäkin Gustafssonin tekijyys oli näyttelyssä häivytetty verrattain vähäiseksi. Hän ei ollut valmistanut tai edes valinnut esillä olevia teosesineitä. Taiteilijan läsnäoloon teosprosessissa ei viitannut myöskään galleriassa ollut teosluettelo: Gustafsson kuten muutkin näyttelyn inmistoimijat eli esineiden lainaajat olivat luettelossa nimettöminä.

Uusien taide-esineiden vastustuksen rinnalla Gustafssonin esille saattama esineistö vastusti myös perinteiseen näyttelyrakenteeseen liittyvää ajallista kestoa. Näyttelyn teostai esine-elementtien ajallisuus vaihteli: kukin esine oli galleriassa vain sen ajan minkä teoksen omistaja halusi. Laina-ajan jälkeen esine palautui omistajalleen, todennäköisesti jatkamaan toimijuuttaan alkuperäisessä arkisessa käyttötarkoituksessaan, mutta kantaen itsessään uusia merkityskerrostumia. Näyttelyn ajallinen liikkuvuus ja epäsäännöllisyys siirsi teoksia osin samankaltaiseen näyttelyvieraan rooliin kuin missä näyttelyssä vierailleet inmisetkin olivat. He ja ne olivat läsnä kukin tavallaan aineellisena ja materiaalisena vieraana, jonka läsnäolo osaltaan vaikutti, muutti ja mukautti näyttelyä. Esineet näyttäytyivät siten prosessuaalisessa tilassa ilman representatiivisia ja etäännyttäviä yhteyksiä johonkin ei-läsnäolevaan toiseen. Tämä ajallinen liikkuvuus tarjosi mahdollisuuden tuoda esiin esineiden merkitysten jatkuva muutos: ne eivät ole koskaan ainoastaan jotain ja yhtä - joko taideteoksia tai arkiesineitä - vaan sekä-että koko ajan. Tämä sekoittunut moninaisuus - transsituationaalisuus - merkitsee sitä, että pysyvien määritelmien sijaan teos kirjoittuu aina ja joka hetki uudelleen.

Gustafssonin näyttelyssä esineet esitettiin yhteydessä omistajiinsa, mikä ylläpiti niiden materiaalisia, historiallisia ja arkisia juuria.
Esineet eivät olleet galleriassa myynnissä, jolloin niiden arvo syntyi irrallaan kaupallisen galleriatilan yhdestä määrittävästä voimasta, rahasta. Raha on suhde, joka yhteismitallistaa - tekee vertailukelpoiseksi - lähes kaiken. Silti sekä Free Shopissa että soap wi-fi stilts -näyttelyssä esineiden ostaminen ja omistaminen onnistuu ainoastaan kulutushyödykkeinä, ei taideteoksina. Molempien esineistöstä puuttuu taiteilijan tietoinen ja päämääräsuuntautunut esteettinen valinta. Tämä eroaa lähtökohtaisesti siitä, kun Marcel Duchamp 1914 kävi ostamassa pariisilaisen tavaratalon kotitalousosastolta pullonkuivaustelineen. Sillä ostotapahtuman jälkeen Duchamp nimesi ja kohotti teline-readymadensa taiteeksi. Tämän nimeämisen jälkeen pullonkuivaustelineellä ei ollut enää pääsyä takaisin "vain" kotitaloustuotteeksi. Hierarkkinen ajatus esineen kohottamisesta taide-esineeksi tarkoittaa esineen materiaalisuuden muutosta: siitä irrotetaan sen alkuperäinen aineellinen yhteys työhön ja jokapäivään, jolloin jäljelle jää sen käsitteellinen puoli, näennäisesti immateriaalinen ajatus katsojan mielessä. Readymaden tarkastelu immateriaalisena käsitteenä irrottaa esineen sen alkuperäisestä tuotanto- ja toimintaket- 
justa ja mahdollistaa teoksen tarkastelun näennäisen neutraalina ja historiattomana - samaan tapaan on kritisoitu Bourriaud'n relationaalista estetiikkaa siitä, että siinä arki näyttäytyy yhtenä ja liian yleisenä. Tämä yleisyys mahdollistaa etäisyydenoton ja representatiivisen suhteen aineelliseen todellisuuteen, ja samalla se riisuu teokselta poliittisen ja aktivistisen voiman.

Free Shopin ja Gustafssonin näyttelyn esineet eivät kuitenkaan ole määritelmällisesti readymadeja, sillä niitä ei uudelleennimetä tai uudelleenasemoida joksikin muuksi. Läpi teos- ja näyttelyprosessin esineet ja asiat toimivat myös kuten ennenkin. Free Shopissa ostokset ja kuitti liikkuvat sujuvasti taideobjektin ja kulutushyödykkeen kategorioiden välissä; suolasaippua Gustafssonin taidenäyttelyssä on samaan aikaan jalustalle asetettu näyttelyesine ja pianistin kosmetiikkatuote. Ne eivät ole joko-tai vaan koko ajan sekä-että.

Osallistava taide onkin koettu taiteentutkimukselle ongelmallisena myös sen vuoksi, että se ei synnytä tai luo esineitä - siitä ei jää juuri mitään aineellista, jota voisi ostaa ja omistaa (ovathan taidehistoria ja taiteen kentän rakenteet pohjanneet vahvassa mielessä taidekaupalle). Nykyaikaiselle esinesuhteelle on sosiologi Turo-Kimmo Lehtosen mukaan tyypillistä, että kaikkiin asioihin voidaan suhtautua ja myös suhtaudutaan kauppatavaroina. ${ }^{28}$ Tämä suhtautumistapa on läpäissyt myös taiteen, kuten John Berger totesi jo 1970-luvulla. ${ }^{29}$ Jos taide on lähtökohtaisesti ostettavaksi tarkoitettu kulutushyödyke, kuten Lehtonen ja Berger väittävät, ovat taiteen esittämis- ja tapahtumispaikatkin annetusti ei-neutraaleja kaupallisia tiloja. Kuluttamisen paradigmaattisuus ja rahan määrittämien suhteiden kaikkiallisuus tulee sekä Free Shopissa että soap wi-fi stilts -näyttelyssä käänteisesti esille. Ne ovat kulutustavaroista koostuvia teoksia, joita ei silti voi teoksina ostaa eikä myydä. Niiden toiminnallisuus on ainakin hetkelliseksi irrottautunut rahan pyörittämästä vaihtotaloudesta - ne ovat onnistuneet sata vuotta varhaisemman dada-liikkeen päämäärässä tuhota ajatus taiteesta kulutushyödykkeenä tai luksustavarana.

Vielä tarkemmin taiteen kauppatavarasuhteen purkamisen on toteuttanut esimerkiksi Cameron Rowland, jonka Indirect Benefit -teoskokonaisuus oli 2016 esillä Fri Art -taidemuseossa Sveitsissä. Indirect Benefit esitteli nyky-yhdysvaltalaista orjuuteen ja rasistisiin oikeuskäytäntöihin kytkeytynyttä talouspolitiikkaa. ${ }^{30}$ Rowland väittää, että orjuus ei ole koskaan poistunut Yhdysvalloista, se on vain muuttunut epäsuoremmaksi. Yhdeksi esimerkiksi epäsuorasta orjuudesta Rowland antaa vankiloihin suljettujen inmisten pakkotyövoiman, joka on julkisen hallinnon toimivuuden kannalta rakenteellisesti välttämätöntä: erilaiset kätketyt hyöty- ja intressiketjut edellyttävät valta- ja alistussuhteiden pysyvyyttä. Rowlandin näyttelykokonaisuudessa oli esillä sellaisia arkisia esineitä kuten oikeussalien yleisöpenkkejä, viemärikaivojen tukirenkaita tai poliisien toimistopöytiä, jotka kaikki oli valmistettu yhdysvaltalaisten vankiloihin suljettujen inmisten palkattomana työvelvoitteena. Rowland esittää historiallisten dokumenttien avulla tämän pakkotyövelvoitteen - jolla on leimallisesti rasistisia juuria - jatkumona orjatyölle.

Koska esineet ovat julkishallintoa varten ja julkishallinnon tilauksesta valmistettuja, ne eivät koskaan tule myyntiin. Rahalla niihin ei pääse käsiksi. Voidakseen esitellä esineistöä ja mahdollistaakseen, ettei niistä kukaan enää edes epäsuorasti hyödy, on Rowland perustanut yleishyödyllisen säätiön, joka on esineet ensin normaalien protokollien mu- 
kaan hankkinut ja sen jälkeen näyttelyyn lainannut. Enää niitä ei voi ostaa eikä niitä voi siirtää alkuperäisiin käyttötarkoituksiinsa. $\mathrm{Ne}$ ovat erkaantuneet rahan ja hyödyn logiikasta todistamaan juuri tätä samaa logiikkaa, muistuttamaan yhteiskunnan rakenteellisesta ja rasistisesta sorrosta.

\section{Taideteoksen transsituationaaliset suhteet}

Kuten todettua, taiteen toimijuuksia voi tarkastella inmisosallistujien ohella myös esineiden näkökulmasta. Teoksissa paljastuvat esinemaailmat ja aineelliset jäljet hajauttavat tarkastelun yli paikkojen ja tilanteiden, transsituationaalisiin suhteisiin. Transsituationaalisessa tarkastelussa teoksella ei ole yksiselitteisesti määrittyvää päättymispistettä, päämäärää tai tavoitetta. Teos luo ympärilleen erilaisia ja osin sattumanvaraisia osallisuus- ja muistikertoimia. Ymmärrän nämä transsituationaaliset suhteet hierarkkisesti litteinä. Kenelläkään tai millään ei koskaan ole täyttä tai ensisijaisempaa pääsyä taideteoksen ehdottamiin maailmoihin. Kaikki teoksessa ja siihen sekoittuvissa aineksissa on nykyhetkestä käsin yhtäläisen tärkeää.
Esimerkiksi Free Shopin kaltaiset interventiot toimivat osallistujiinsa nähden ainakin kahdella ajallisuuden tasolla: välittömyyden ja viiveen kautta. ${ }^{31}$ Välittömyys syntyy osallistavan intervention suorasta luonteesta. Teos toteutuu samalla kun siihen osallistutaan. Tämän välittömyyden ajatellaan usein olevan esimerkillinen tai oikea tapa osallistua teokseen. Toisaalta teos tapahtuu myös viiveellä32: muut kuin teokseen välittömästi osallistuneet pääsevät siihen jälkikäteen osallisiksi teosprosessista syntyneiden dokumenttien, tallenteiden, suullisten tiedonantojen sekä muiden epäsuorien aineellisten materiaalien välityksellä.

Tämä viive tuo teoksen tarkasteluun epävarmuuksia. Esimerkiksi Martha Buskirk toteaa, kuinka teokseen viiveellä osallistuvien pitää "luottaa" taiteilijan kertomukseen teoksesta. ${ }^{33}$ Hän siis painottaa luottamusta siihen, että taiteilija kykenisi tavoittamaan teoksesta jonkin kiinteän teoshahmon, johon kokemus voitaisiin viiveelläkin palauttaa - vaikka tuo kokemus onkin välittyneempi ja siten sekä laadullisesti heikompi että kokemuksellisesti ohuempi. Buskirk rakentaa näin hierarkkisen suhteen teoksen välittömän ja viiveellä tapahtuvan vastaanoton välille, mikä ylläpitää etuoikeuksia ja portinvartijuutta suhteessa teoksen synnyttämään tietoon ja kokemukseen. Tämän rakenteellisen portinvartijuuden transsituationaalisuuden ajatus kumoaa.

Teosten transsituationaalisuus merkitsee taiteentutkimuksessa myös dualistisen materiaalinen-immateriaalinen-asetelmallisuuden purkamista. Transsituationaalisuutta leimaa moninaisten toimijuuksien epämääräisyys, epälineaarisuus ja tunnistamattomuus. Se myös aktivoi teoksen katsomis- ja vastaanottokokemuksen kriittisenä harjoitteena, jossa ei ole yksiselitteisesti oikeaa positiota suhteessa teokseen. ${ }^{34}$ Siksi transsituationaalisuuden ajatus, taideteoksen ymmärtäminen liikkuvina suhteina korostaa taiteesta kirjoittamisen poliittisuutta: siirtymää läsnäoloon ja nykyhetkestä käsin syntyvän teosluennan eettisyyteen ja vastuullisuuteen. Tällöin tutkimuksellista mielenkiintoa ja katsetta teokseen ja sen prosessiin ei ainoastaan hajauteta vaan palautetaan teoksesta näennäisesti puuttuvien keskiöiden väliin ja liitoksiin, esineisiin ja asioihin; niihin moninaisiin aineellisiin toimijoihin, jotka tuovat moneuden yhteen. Teokseen on aina aktiivisesti rakennettava uusi suhde nykyhetkestä 
käsin: se on kirjoitettava uudelleen. Transsituationaalisuus ja siihen sisältyvä kirjoittamisen poliittisuus avaavat mahdollisuuden kritisoida ja purkaa toimimattomia taiteentutkimisen protokollia. Siten tieto ei ole kumulatiivista ja karttuvaa - tai edes itsekorjaavaa. Transsituationaalisuus harjoitteena tuottaa (taide-)esineille kerronnallisen korpuksen, joka ei ole lineaarista, kronologista eikä yksinomaan inmis- tai instituutiokeskeistä.

\section{Binäärisyyden purku monin- ja uudelleenkirjoittaen}

Modernistinen taide perustui selkeään kaksinapaisuuteen. Taideteoksen vahva ja yksiääninen läsnäolo edellytti etäisyyttä teoksen ja sen tarkastelijan välille sekä erillisyyttä muusta maailmasta, ${ }^{35}$ mikä voimakkaasti eriarvoistaa ja ylläpitää taiteen vastaanottotilanteen valtasuhteita. Tämä ajatus taiteen ja kaiken muun erillisyydestä on kiinteä ja fundamentalistinen puhdasoppisuuden rakenne, jota tulee moniarvoisessa yhteiskunnassa aktiivisesti kritisoida. Kiinteät jaottelut esimerkiksi taiteilijan ja katsojan, subjektin ja objektin, taideteoksen ja arkiesineen, taiteen ja ei-taiteen sekä materiaalisen ja immateriaalisen välillä kyseenalaistuvat viimeistään taiteen transsituationaalisissa tarkasteluissa. Luonnehtiihan nykytaidetta usein toimijuuksien epämääräisyys, epälineaarisuus ja tunnistamattomuus sekä teoksen aineellisten jälkien ja suhteiden kanssatoimijuus.

Taiteen binääriset rakenteet ilmaisevat keinotekoista universalismia, yleisyyttä joka taiteen käytännössä johtaa helposti normatiivisuuteen ja totalisoivaan diskurssiin. Näennäisen neutraali yleinen diskurssi ylläpitää juuri niitä hegemonisia rakenteita ja alistavia tai sortavia käytäntöjä, joita taiteen tulisi jatkuvasti kritisoida ja haastaa. Se estää uuden ja moniarvoisemman tiedon esilletulon. Institutionaalinen taidehistoria on toistuvasti ottanut tehtäväkseen luoda pysyvyyttä ja arvoa taiteelle ja teoksille - keinotekoisen illuusion taiteen ikuisuudesta ja yleisyydestä. Tämä taiteen ylläpitävä ja rajaava funktio samalla ylläpitää taiteeseen - ja siten koko yhteiskuntaan - sisäänrakennettuja väkivaltaisia ja toiseuttavia valtarakenteita. Teoksia tarkastellaan eheinä tarinoina irti koko kontekstistaan ja materiaalisista ympäristöistään, joihin annetusti sisältyy häiriöitä, epätäsmällisyyksiä ja katseelle kitkaa tuottavia sisältöjä. Siinä missä orjakauppiaiden patsaita kaadetaan ja taiteen kaanoneita uudelleenarvioidaan esimerkiksi Black Lives Matter -liikkeen yhteydessä, tulee teosta tarkastellessa kysyä ja uudelleenkysyä, minkälaisiin arvoihin ja poliittisiin ja yhteiskunnallisiin sisältöihin teos ja teoksen tarkastelijan toimijuus paikantuvat. Taide, kuten elämäkin, on aina kaksijakoista, muttei perustuen joko-tai-ajatteluun vaan ja-sanan aktiiviseen käyttöön. Taide on sekä-että. Samanaikaisuuksina, muutoksina, liikkeinä ja vaihteluina hetkellisyyden ja ikuisuuden, kiinteän ja häilyvän, yksilöllisen ja yhteisöllisen seassa. Ei yksiä ilman toisia, eikä toisia ilman kolmansia; ei teosta ilman määrittäjiä, eikä määrittäjiä ilman erilaisia transsituationaalisia konteksteja.

Osallistavan taiteen aineellinen moninaisuus kutsuu ja tallentaa itseensä vieraanvaraisesti kaiken, niin kutsutut kuin kutsumattomatkin. Niitä voi ajatella esimerkkeinä feministifyysikko Karen Baradin ${ }^{36}$ toimijuusrealismista: ne ovat erilaisten ja yhteismitattomien asioiden, esineiden ja inmisten muodostamaa sekoittunutta toimijuutta. Tämä yhteistoimijuus pohjaa horjuviin ja huojuviin suhteisiin, joissa kieli ja normatiiviset kategoriat eivät tarjoa varmuutta ja turvaa. Se itsessään on uutta, huokoista ja poeettista ilmausta. Erilaisuuden salliessaan teokset 
asettuvat alttiiksi tiedoille ja prosesseille, joiden sisällöistä ja suunnista ei ole varmuutta ja jotka hyväksyvät sotkuisuuden ja tilannesidonnaisuuden positivistisen selkeyden laatimisen sijaan. Taideteoksen määritelmä ei ole sama ja pysyvä vaan määritelmät liikkuvat ja vaihtuvat eri tilanteissa ja erilaisissa suhteissa. Se mahdollistaa taiteen kehityskertomuksen sijaan ei-loogista ja ei-lineaarista, sotkua ja epäyhteneväisyyttä; lumoutumisen ja magian sallimaa ruumiillisuutta, kielen ja sanojen ilmaisukyvyn koko kapasiteetin käyttöönottamaa moninaisuutta. Se hyväksyy myös ei-tietämisen ja ei-tuntemisen: sen, että teokseen aina jää asioita, joita ei voi tietää eikä tuntea kokonaan.

Kun tunnustaa teosten ja toimijuuksien ambivalenssin, avautuu mahdollisuus nyt-hetkestä ja siihen sisältyvistä kiireellisistä asioista nousevaan uuteen tietoon, säröihin tai deleuzelaisittain ajateltuna paon viivoihin ohi vallitsevien selitys- ja tulkintaketjujen. ${ }^{37}$ Silloin teoksen kanssaoleminen tarjoaa pääsyn myös yllättävään ja ennakoimattomaan eettiseen suhteeseen. Särön mahdollisuus tarkoittaa jonkin särkymistä, rakoilua ja rikkoutumista tai irti päästämistä - oli kyse sitten uskomuksista, ajattelumal- leista, pysyvyydestä tai paradigmoista. Särö luo ja rakentaa uusia topologioita ja moninkirjoittamisen tapoja. ${ }^{38}$

Transsituationaalisuuden tunnistaminen ei muuta tapaa tarkastella taidetta. Se vain muuttaa ja osoittaa sen eettisen välttämättömyyden, että kaikki tulee arvioida aina uudestaan nykyhetkestä käsin. Vain silloin teokset tulevat liitetyiksi myös laajempiin eettisiin yhteyksiinsä ja taidehistorian tieto säilyy elinvoimaisena. Teosten materiaalisuus luo pohjan, jolla ne kiinnittyvät toiminnallisesti poliittisiin, taloudellisiin ja sosiaalisiin kysymyksiin. Tällöin (taiteen) historioitsijan tehtäväksi tulee tuoda takaisin tietoisuuteen yhteiskunnassa jo unohdetut mutta edelleen vallitsevat asiat - jotta voidaan mennä eteenpäin.

Tällaisia nykyisyyden luonnetta voimakkaasti määrittäviä mutta jo tapahtuneita asioita ovat esimerkiksi 1800-luvun lopun teollisen vallankumouksen synnyttämä ja nyt luonnollistunut ylikulutus ja luonnonvarojen tuhlaaminen, joka ilmastokatastrofista huolimatta kasvaa edelleen. ${ }^{39}$ Teollistumisen ja siihen liittyvän kapitalistisen edistysuskon kuvat näkyvät muun muassa Free Shopin ilmaisen ostamisen utopiassa ja käänteise- nä soap wi-fi stilts -näyttelyn taide- ja arkiesineistön keskinäisessä vaihdettavuudessa ilman uutuuden vaatimusta. Kolonialismin ja orjakaupan sietämättömän väkivaltaiset kuvat tulevat traagisesti esiin esimerkiksi Indirect Benefit -näyttelyn viimeistellyn tyylikkäissä ja funktionaalisissa toimistohuonekaluissa.

\section{Lopuksi}

Taide usein mielletään harvinaisten, singulaarien, yksittäisten ja autenttisten esineiden kokoelmaksi. Tällaista ilmiselvää erityisyyttä ei Free Shopin tai soap wi-fi stilts -näyttelyn esineillä ole. Ne ovat kiistatta jokapäiväisiä ja yleisiä. Monesti osallistamiseen painottuneiden teosten materiaalisuus onkin banaalia, satunnaista eikä millään tavalla huomionarvoista tai edes esteettistä: ne olivat jo-siellä. Ne edelsivät interventiota ja jäivät sinne intervention jälkeen. Siitäkin huolimatta tällaisilla mahdollisesti arkipäiväisillä esineillä on keskeinen rooli inmisten yhteen tuomisessa ja kommunikaation luojina: ne toimivat ihmistenvälisen yhdessäolemisen aineellisina välittäjinä. Silti esineiden korostaminen ei merkitse paluuta taiteen formaaleihin esteettisiin tai historiallisiin sisältöihin vaan ennen 
kaikkea esineiden ja asioiden huomioimiseen osallistavan taiteen aktiivisina toimijoina. Siten ymmärrän materiaalisuuden roolin eräänlaisena synnyttäjänä, muokkaajana ja itseään laajemman muodon antajana. Esineet kuljettavat, muokkaavat ja vaikuttavat.

Siksi ehdotan tässä tekstissä taiteen erityiseen rajaamiseen ja kategorioiden ylläpitämiseen pohjautuvan neuvottelun rinnalle moninaisuutta ja sallivuutta: ja-sanan käyttöä dualismien sijaan. Taiteen transsituationaalisuus - ja siten myös epävarmuus ja ambivalenssi - luo marginaalien dynamiikkaa, muutosta ja liikettä, joka tasa-arvoistaa ja moninaistaa myös taidehistorian tutkimusta. Epävarmuuden tunnustaminen tekee taiteesta kirjoittamisesta poliittisesti ja eettisesti vastuullisen harjoitteen, jolla etsiä kestävää suhdetta myös vieraisiin tai taiteeksi tunnistamattomiinkin aineellisiin elementteihin.

Aloitin tekstini siteeraamalla Douglas Huebleria ja hänen havaintoaan siitä, kuinka maailma on täyttymässä tavaroihin. Free Shopin dokumenttikuvat osoittavat juuri tämän tavaroiden määrättömyyden: niissä paljastuu kulutettavaksi tarkoitettujen tavaroiden houkutus ja runsaus. Myös Kenneth
Goldsmith $(2011)^{40}$ on viitannut Huebleriin luonnehtiessaan epäluovaa kirjoittamista (uncreative writing). Goldsmithiä soveltaen epäluova taide ei olisi luovuuden puutetta vaan ennen kaikkea kieltäytymistä tuottamasta maailmaan lisää sitä, mikä jo lähtökohtaisesti on ongelma ja haaste: esineitä, yleisyyttä, samuutta. Juuri goldsmithiläiseen epäluovuuteen myös Tatu Gustafssonin näyttelyynsä lainaamat kulutushistorialliset esineet transsituationaalisesti tarttuvat.

\section{Viitteet}

1 "The world is full of objects, more or less interesting; I do not wish to add any more." Douglas Huebler, Statement, 1969, luettu 2.7.2020, , http://www.ubu. com/papers/huebler statements.html.

2 Niin sanotusta aineettomasta taiteesta käytetään kontekstista riippuen erilaisia termejä, kuten

esimerkiksi ephemeral, intangible, dematerialized, immaterial, objectless ja conceptual art. Keskustelun aineettomasta taiteesta käynnistivät Lucy Lippard ja John Chandler 1968 julkaistulla artikkelillaan "The Dematerialization of Art", Art International 12, no. 2 (February 1968): 31-36.

3 Muun muassa Claire Bishop on määritellyt

osallistavan taiteen kolmen tunnusomaisen piirteen mukaan: se 1) aktivoi katsojaa, 2) haastaa perinteisen tekijyyden tasa-arvoistamalla taideteoksen

luomisprosessia sekä 3) muokkaa yhteisöjä. Claire Bishop, "The Social Turn: Collaboration and its Discontents", Artforum (February 2006).

4 Free Shopin kaksi ensimmäistä toteutuskertaa olivat vuonna 2003 Tokiossa ja Bremenissä, minkä jälkeen se on uusittu eri puolilla maailmaa erilaisten taidetapahtumien ja -festivaalien yhteydessä. Ks. esim. Riikka Haapalainen, Utopioiden arkipäivää: Osallistumisen ja muutoksen paikkoja nykytaiteessa 1980-2011 (Helsinki: Unigrafia, 2018), 125, 148;

Superflex, Free Shop: Anything the Customer Wants to Purchase is Free (Copenhagen: Pork Salad Press, 2009).

5 Superflex, Free Shop, 2009.

6 Termi on omani, ks. lisää Haapalainen, "Utopioiden arkipäivää", 13, 29.

7 Moninlukeminen on kehittämäni käsite, jolla viittaan samanaikaisesti vaihtoehtoisiin teoksen luentatapoihin.

8 Klassinen esimerkki taiteen kontemplatiivisesta vastaanotosta ks. Johann Joachim Winckelmann, Jalosta yksinkertaisuudesta: Kirjoituksia antiikin taiteesta ja arkkitehtuurista, suom. Vesa Oittinen 
(Helsinki: VAPK-kustannus, 1992).

9 Bishop, "The Social Turn: Collaboration and its Discontents", 8.

10 Suzana Milevska, "Participatory Art: A Paradigm Shift from Objects to Subjects", Springerin 6, no. 2 (Feb. 2006), luettu 1.8.2020, https://www.springerin. at/en/2006/2/partizipatorische-kunst/

11 Myös Latour luonnehtii inmisten ja asioiden välittämää sosiaalista vuorovaikutuksen maailmaa

jo valmiina olevana: already-there, ks. Bruno Latour, "On Interobjectivity", Mind, Culture, and Activity 3, no 4 (1996): 234, luettu 1.8.2020, http://www.brunolatour.fr/sites/default/files/63-INTEROBJECTS-GB. pdf.

12 Ks. Roland Barthes, Tekijän kuolema, tekstin syntymä, suom. Lea Rojola \& Pirjo Thorel (Tampere: Vastapaino, 1993); Olli Pyyhtinen, "Geometrista sosiologiaa", Tiede ja Edistys 2, nro 27 (2002): 161-162.

13 Irit Rogoff, "Looking Away - Participating Singularities, Ontological Communities" (IKKM Research project, 2011), 133, luettu 15.6.2020, http:// www.ikkm-weimar.de/en/fellows/former-fellows/iritrogoff/. Katso myös Latourin ajatus toimijuudesta aktiivisesti todellisuutta muokkaavana, koettelevana elementtinä. Latour, Reassembling the Social: An Introduction to Actor-Network-Theory (Oxford: Oxford University Press, 2007), 205.

14 Maria Lind, "The Collaborative Turn", in Taking the Matter into the Common Hands: Contemporary Art and Collaborative Practices, ed. Johanna Billing, Maria Lind \& L. Nilsson (London: Black Dog, 2007), 17.

15 Nicolas Bourriaud, Relational Aesthetics (DijonQuetigny: Les presses du reel, 2002).

16 Bourriaud, Relational Aesthetics, 45.

17 Claire Bishop,"Antagonism and Relational

Aesthetics", October 110 (Fall 2004): 64-65.

18 Claire Bishop, Artificial Hells: Participatory Art and the Politics of Spectatorship (London: Verso, 2012), passim.
19 Bishop, "The Social Turn", 10.

20 Latour, "On Interobjectivity", 1996, passim. Ks. myös Turo-Kimmo Lehtosen luonnehdinta materiaalisuuden merkityksestä yhteisöjen ylläpitämisessä ja luomisessa. Turo-Kimmo Lehtonen, Aineellinen yhteisö (Tutkijaliitto: Helsinki, 2008).

21 Ylipäätään taiteen jaottelu puhtaasti aineettomaan ja aineelliseen on ongelmallinen. Esimerkiksi Graham Harmanin esittelemä ooo-teoria (objectoriented-ontology) väittää, että mikään ei lopulta ole aineetonta, vaan kaikella on aineellinen perusta. Graham Harman, Object-Oriented Ontology: A New Theory of Everything (London: Pelican Books, 2018), 43.

22 Michel Maffesoli, Maailman mieli. Yhteisöllisen tyylin muodoista, suom. Mika Määttänen (Helsinki: Gaudeamus, 1995), 140-144.

23 Ks. esimerkiksi Pablo Helguera, Education for Socially Engaged Art: A Materials and Techniques Handbook (New York: Jorge Pinto Books, 2011); Kaija Kaitavuori, Art of Engagement: Audience Participation and Contemporary Art (London: Courtauld Institute of Art, University of London, 2015).

24 Ks. Latour, "From Realpolitik to Dingpolitik, or How to Make Things Public", in Making Things Public: Atmospheres of Democracy, ed. Bruno Latour \& Peter Weibel (Cambridge, MA: The MIT Press, 2005), 14-41.

25 Harman, Object-Oriented Ontology. 26 Jane Bennett, Vibrant Matter: A Political Ecology of Things (Durham, NC: Duke University Press, 2010).

27 soap wi-fi stilts 2.-25.8.2019, Titanik-galleria lehdistötiedote, luettu 15.6.2020, http://www.titanik.fi/ soap-wi-fi-stilts/.

28 Lehtonen, "Aineellinen yhteisö", 84.

29 John Berger, The Ways of Seeing (London: Penguin Books, 1971).

30 Cameron Rowland, Indirect Benefit, exhibition booklet (Fri Art, 2016), luettu 7.7.2020, https://www. fri-art.ch/sites/default/files/2016-09/Indirect $\% 20$ Benefit\%20Booklet 1.pdf.
31 Martha Buskirk, The Contingent Object of Contemporary Art (Cambridge, MA: The MIT Press, 2003), 217. Viive ja välittömyys luennassani eivät sisällä hierarkkista tai muutoin arvottavaa eroa. 32 Ibid.

33 Ibid., 218.

34 Tämä merkitsee Donna Harawayn paikallistuneen tiedon ajatuksen aktiivista soveltamista. Ks. Donna Haraway, "Situated Knowledges: The Science

Question in Feminism and the Priviledge of Partial Perspective", Feminist Studies 14, no. 3 (1988): 575-599.

35 Ks. esim. Clement Greenberg,

"'Amerikkalaistyyppisestä' maalauksesta", suom. Leevi Lehto, teoksessa Modernin ulottuvuuksia. Fragmentteja modernista ja postmodernista, toim. Jaakko Lintinen (Helsinki: Kustannusosakeyhtiö Taide, 1989), 104-132.

36 Karen Barad, "Posthumanist Performativity: Toward an Understanding of How Matter Comes to Matter", Journal of Women in Culture and Society 28 no. 3 (2003): 801-831.

37 Karl Marx kuvasi säröllä tai raolla kapitalistiselle taloudelle vaihtoehtoista kommunikatiivista suhdetta arkeen (Bourriaud, Relational Aesthetics, 45,

16). Laajemmin särö merkitsee minkä tahansa uuden mahdollisuuden ilmaantumista vallitsevien uskomusten ja ideologioiden takaa.

38 Luomallani moninkirjoittamisen käsitteellä hahmotan teosluentaa, joka pitää sisällään erilaisten kirjoittamistapojen moninaisuuden ja tapojen välisen vaihdettavuuden. Se siten sallii vastuullisen moneuden synnyttämisen ja ylläpitämisen taiteessa ja sen luentatavoissa. Huom. moninkirjoittaminen ei ole toisinkirjoittamista. Ajatus toisinkirjoittamisesta pitää yllä hierarkkista suhdetta suhteessa alkuperäiseen tai vallitsevaan kirjoittamisen tai luennan tapaan. Siten se implikoi vain vaihtoehtoisuutta ja myöntyy keskiön a marginaalin väliseen binääriseen suhteeseen. 39 Vrt. Susan Sontag on rinnastanut kuluttamisen syövän ja tuberkuloosin kaltaisiin tauteihin (tautien

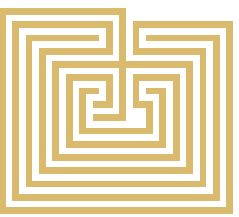


tapaa näivettää inmistä kuvailtiin juuri kuluttamisena) Susan Sontag, Sairaus vertauskuvana \& Aids ja sen vertauskuvat, suom. Osmo Saarinen (Hämeenlinna: Karisto, 1991)

40 Kenneth Goldsmith, Uncreative Writing: Managing

Language in the Digital Age (New York: Columbia

University Press, 2011).
FT Riikka Haapalainen on taidehistorioitsija ja kasvatustieteilijä, joka toimii vanhempana yliopistonlehtorina Aalto-yliopiston taiteen laitoksella. Haapalaisen tutkimus- ja opetusaloina ovat muun muassa avantgarden ja nykytaiteen teoriat, taiteen osallistavat ja sosiaaliset prosessit sekä näyttelypedagogiikka ja kriittinen museotutkimus.

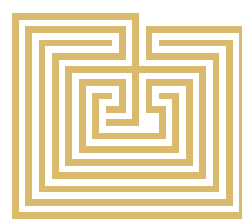

